The Impact of Employer Brand on Faculty Members Retention ...

Afnan mamdouh el sayed huessin barakat

\title{
The Impact of Employer Brand on Faculty Members Retention in the Egyptian Universities
}

\section{Afnan mamdouh el sayed huessin barakat}

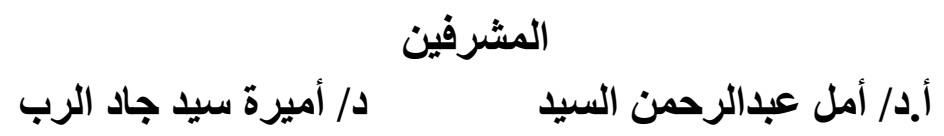

\section{Abstract:}

This research presents information on employer branding and faculty members retention as a critical issue in the higher education sector in Egypt and creates an understanding of the importance of the concept in an organizational context. The research analyzes three dimensions, i.e., development value, economic value, and application value and examines their impact on faculty members retention. By applying to the higher education sector in Egypt a comparative study between public and private universities.

The researcher found that the employer brand has a partial effect on the retention of faculty members in higher education in Egypt. There is no difference in the impact of the employer brand on the retention of faculty members in private universities than in public universities. Development value was the most influential factor on faculty members' retention, followed by application value. Economic value has no effect on faculty retention in universities.

Keywords: employer branding, employee retention, development value, economic value, application value.

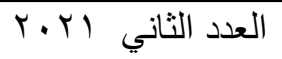

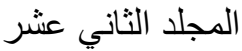


The Impact of Employer Brand on Faculty Members Retention ...

Afnan mamdouh el sayed huessin barakat

\section{Introduction:}

Today's employees, in particular the competent and distinguished, are looking for an employer who improves their experience, skills and knowledge and provides an enjoyable and stimulating work environment (Younis \& Hammad,2020). When an individual searches for a job, he/she asks about the value he/she will gain from employment in a particular organization. Organizations raced to market themselves in the job market as the best place to work, to attract and retain talent. In 1996, Ambler \& Barrow coined the concept of employer branding. Employer branding is the image of the organization as an employer from the point of view of potential and current employees. Some studies have demonstrated the positive effects of the employer branding strategy on the behaviors and performance of current and potential employees and the performance of the organization as a whole (Biswas\& Suar, 2016; Younis,2020).

Due to globalization, technological advancement, and talent war, competition among organizations for talented people in the labor market has increased (Kyndt et al., 2009; Fasih et al.,2019).

Organizations are experiencing an increase in employee turnover and the need for strategies to retain employees, especially the talented ones, has emerged (Backhaus, 2016). This responsibility falls on the shoulders of the human 
The Impact of Employer Brand on Faculty Members Retention ...

Afnan mamdouh el sayed huessin barakat

resources department in any organization (Hamidzadeh \& Fardi, 2019; Ibrahim et al.,2018).

\section{Literature review}

\subsection{Literature related to employer brand}

Chawla's (2019) study aimed to explore whether employer branding programs lead to a high level of engagement among employees in the service sector, while also analyzing the mediating influence of appropriate person-organization fit (PO) on the relationship between relevance person-organization fit and EB. Primary data were collected through questionnaire distributed to employees and HR working in off-call centers in India. The research results showed that employer branding had a positive relationship with personal -organizational fit and employee engagement. The results also reveal that the impact of personal and organizational fit had a partial mediating effect on the relationship between employer branding and employee engagement.

Gregorka et al., (2020) aimed to examine how Portuguese IT and engineering companies developed their most attractive employer branding and examine role of HRM in EB's process. These companies were selected based on the most attractive Portuguese IT and engineering companies according to the 2016 Trendence Graduate Barometer study. Data were collected through an in-depth semi-structured interview with the companies' HR representatives. This study confirmed the

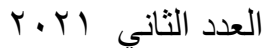

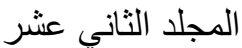


The Impact of Employer Brand on Faculty Members Retention ...

Afnan mamdouh el sayed huessin barakat

prominent role of human resource management in the executive board process. Businesses developed their EB program by creating a distinctive employer value proposition (EVP) and offering attractive benefits to attract and retain talented employees. Emotional motivation, i.e., non-monetary EVP, had a greater effect on employees than rational motivation, i.e., monetary EVP. The results confirmed that employees value training and development activities, or Career growth opportunities, more than a one-time financial reward.

\subsection{Employee Retention: -}

In accordance with the global and dynamic competition, human resource management in organizations develops new strategies and policies to maintain and improve its position in the market (Hamidzadeh \& Fardi, 2019). Organizations have various types of assets; human resource is considered to be the most important asset. Skillful and competent employees help organizations achieve their goals and reach a distinctive position in the market (Matimbwa \& Ochumbo, 2019). The methods used by the organization in managing its employees affect its image in the labor market and in turn affect the intention of the employees to stay or leave their organizations. So, the organization needs to find ways and strategies to achieve its goals and improve its image and reputation in the market etc. through retaining and developing talented employees.

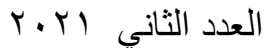

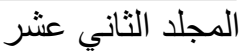


The Impact of Employer Brand on Faculty Members Retention ...

Afnan mamdouh el sayed huessin barakat

\section{History of Employee Retention Concept}

Employee retention of key and valuable employees is significant for an organization and responsible for an organization's performance and productivity. Interest appeared in employee retention from the twentieth century when scientists began to search for reasons motivating employees to leave work and factors affecting their job performance (Bibi et al.,2018). Recently, researches have increased on employee retention as a talent management tool. Employee retention strategies are increasing as the most important organizational challenge to the workforce in the contemporary world (Javed \& Jaffar, 2019).

Moore et al., (2020) explored employee perceptions according to good or bad human resource management practices and their impact on employee satisfaction, retention, engagement, and ability to recommend an employer. This study was applied to 168 employees in dairy farms in the United States. The analysis of the collected data through questionnaires showed that the most important factor that affects all of the above is the relationship with supervisors. As this study confirmed that if employees leave their work, they leave the managers and not the organization. The quality of relationships with supervisors also affected employees' participation and willingness to recommend their farms to others.

The United States suffers from high academic attrition, so Miller \& Youngs (2020) examined the role of several measures

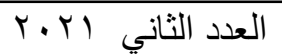

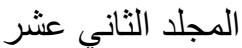


The Impact of Employer Brand on Faculty Members Retention ...

Afnan mamdouh el sayed huessin barakat

of person-organization fit, teaching colleagues, teaching assignment, principal observation, student characteristics, and mentoring support in retaining first year teachers in three states, Connecticut, Michigan, and Virginia. Data were collected from 159 program candidate and graduate teachers from five public universities. The data analysis found that the match between appropriate first-year teachers' person-organization fit and their teaching colleagues had a stronger relationship with teachers' decisions to stay in their schools than school characteristics, teacher characteristics, and major or mentoring activities.

\subsection{The relationship between employer brand and employee retention}

Studies have confirmed that a reputable employer brand is able to retain employees if promises are fulfilled and the expectations of its employees are met (Mostafa \& Hassan,2020).

The strong employer branding results in employee retention. The outcomes from implementing an employer brand strategy were employee satisfaction and commitment, psychological needs met, and employee retention. (Tanwar \& Prasad ,2016). They suggested making employer brand results antecedents for employee retention.

It proved that if the employer branding strategy is properly implemented by creating a motivating work environment and gaining employee satisfaction, the organization will be able to differentiate itself among its competitors in the labor market and

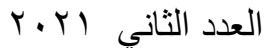

المجلد الثاني عشر 
The Impact of Employer Brand on Faculty Members Retention ...

Afnan mamdouh el sayed huessin barakat

become the employer of choice, which increases and improves its ability to retain competent and talented employees. When the employee feels that he or she is working in the best organization on the market in an effective work environment, characterized by respect and encouragement, that meets his/her expectations, improves his/her skills, he or she becomes satisfied with the organization, and his/her loyalty to it and his/her desire to continue with it increases. So, it is important for organization owners to understand the importance of employer branding and the consequent desirable organizational outcomes (Gilani\& Cunnin- gham,2019).

A feature of employer branding that is organizational support had an impact on employee retention. Organizational support has a positive effect on employee retention. Employees prefer to work in a motivated and supportive environment. Organizational support is one of the value propositions for an employer's brand (Arasanmi \& Krishna, 2019).

The employer branding had a positive effect on employee retention, and the organization could capitalize on the employer's strong branding by reducing compensation package offerings to employees (Bussin \& Mouton, 2019).

\section{Research Problem:}

After reviewing the literature review handling the same research topic and the results obtained from conducting the exploratory study, the researcher can reach the current research 
The Impact of Employer Brand on Faculty Members Retention ...

Afnan mamdouh el sayed huessin barakat

problem which is summarized in the attempts to answer the main question of the research and the following sub-questions as follows:

what is the relationship between the employer branding and the retention of faculty members in public and private universities in Egypt?

The sub-questions are as follows:

- What is the relationship between development value and the retention of faculty members in public and private universities?

- What is the relationship between economic value and the retention of faculty members in public and private universities?

- What is the relationship between application value on the retention of faculty members in public and private universities?

- What is the relationship between social value and the retention of faculty members in public and private universities?

- What is the most significant factor affecting retention of faculty members in public and private universities?

- Are there significant differences between public universities and private universities with regard to the relationship between the brand of the employer and the retention of faculty members in these universities? 
The Impact of Employer Brand on Faculty Members Retention ...

Afnan mamdouh el sayed huessin barakat

\section{Research Objectives}

This research seeks to achieve the following objectives:

1. Determining the strength and direction of the relationship between the brand of the employer and the retention of faculty members in the selected universities, and how the brand of the employer contributes to achieving the retention of these members.

2. Determining the dimensions of the brand of the employer that has a significant impact on retaining faculty members in the selected universities.

3. Determining the dimensions of the employer brand that has the most significant influence on retaining faculty members in the selected universities.

4. Knowing whether a university with a strong employer brand is able to retain its faculty members.

5. Examining the extent of the presence of significant differences between public universities and private universities with regard to the relationship between the brand of the employer and the retention of faculty members in these universities. 
The Impact of Employer Brand on Faculty Members Retention ...

Afnan mamdouh el sayed huessin barakat

\section{Research model}

Independent variable

Dependent variable
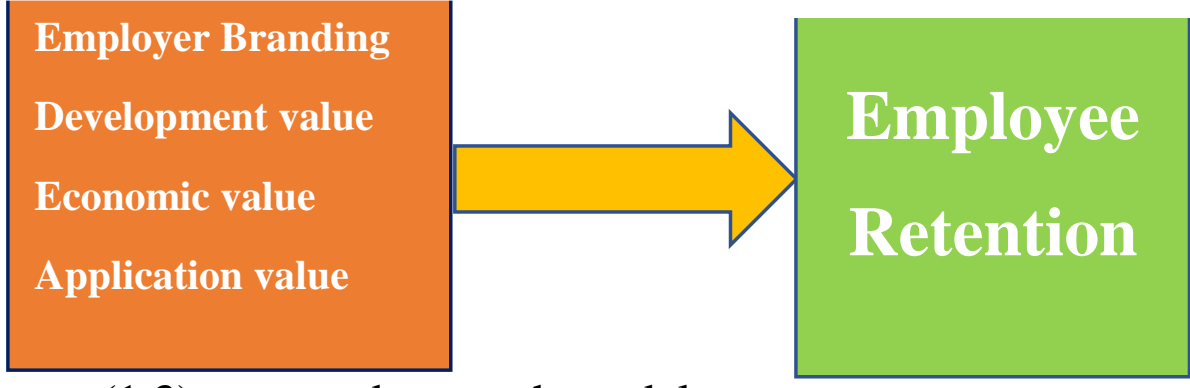

Figure (1.3) proposed research model

source: prepared by the researcher

\section{Hypotheses Formulation}

This research is based on testing the following hypotheses:

\section{The first main hypothesis:}

According to the related literature and the research objectives, the previous studies argued that there is a positive relationship between employer brand and retention (Hadi \& Ahmed,2018; Bussin \& Mouton, 2019; Cilani \&Cunningham,2019; Matimbwa \&Ochumbo,2019). So, the researcher can formulate the first hypothesis as follows:

The first main hypothesis: There is a significant direct and positive relationship between employer brand and faculty members' retention.

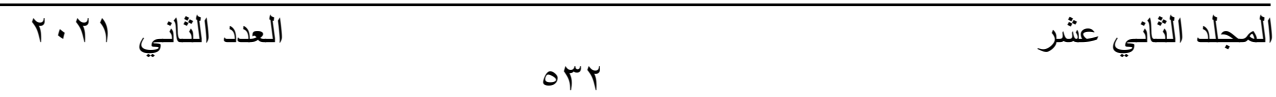


The Impact of Employer Brand on Faculty Members Retention ...

Afnan mamdouh el sayed huessin barakat

\section{A. The first sub- hypothesis:}

Development value has an impact on employee attitude such as commitment and retention (Wadhawan \& Sinha, 2020; Mostafa \& Hassan,2020). The value of development has a positive impact on the organizational commitment which is reflected in employee satisfaction (Towns, 2019). Satisfaction is the factor responsible for employee retention in any organization (Towns, 2019; Butta et al., 2020).

Training and development are one of the most important HRM practices. The organization works to develop its staff and provide them with the required skills and training programs that help them to advance, and this has an effective impact on staff retention and loyalty to their organization (Tanwar \&Prasad, 2016; Ahmed \& Daud, 2016; Kossivi et al., 2016; Hadi \& Ahmed,2018; Bussin \& Mouton, 2019). Thus, the researcher can formulate the first sub-hypothesis as follows:

\section{H1a: There is a significant direct and positive effect between development value and faculty members' retention.}

\section{B. The second sub-hypothesis}

There is a debate on the impact of compensation on employee retention. Literatures agreed that there is no impact of compensation on retention (Ahmed \& Daud,2016; Hadi\&Ahmed,2018). Other studies agreed that compensation has a positive impact on retention (Kossivi et al.,2016; Sarmad et al. ,2016; Tanwar \& Prasad, 2016; Bibi et al., 2017; Butta et 
The Impact of Employer Brand on Faculty Members Retention ...

Afnan mamdouh el sayed huessin barakat

al.,2020). Employee satisfaction with their salaries results in love for the organization and creates positive trends in employee behavior, including commitment and retention of the organization( Tanwar,2017). Economic value contributes to employee satisfaction and motivation to work (Tanwar \& Prasad, 2016). Economic value includes job security, retirements plan, and high salary (Wadhawan\& Sinha,2020).

\section{H1b: There is a significant direct and positive effect between economic value and faculty members' retention.}

\section{The third sub-hypothesis:}

The value of the application contributes to the success of the employer's brand and the creation of innovative services and products by helping and encouraging employees to apply what they have learned and share their knowledge and skills in a meaningful way (Dabirian et al., 2019).

H1c: There is a significant direct and positive effect between application value and faculty members' retention.

\section{The second main hypothesis}

Previous studies proved that the development dimension of the employer brand had a greater effect on faculty members' retention than the other dimensions (Wadhawan\& Sinha,2020). Also, the researcher found through the exploratory study that development value had an impact on employee retention. So, the researcher can formulate the second main hypothesis as follows: 
The Impact of Employer Brand on Faculty Members Retention ...

Afnan mamdouh el sayed huessin barakat

The second main hypothesis: Development value is the most affecting factor on faculty members' retention.

\section{The third main hypothesis}

Universities are developing at the present time, especially private universities, to distinguish themselves and attract students, which drives universities to attract and retain qualified and talented faculty members. With the great competition between public and private universities for faculty members, and the great competition in the private higher education sector as a result of the increasing number of private universities. The opportunities for faculty members, especially those with high skills, qualifications and talents, result in less loyalty and less faculty retention( Mostafa et al.,2021).

The third main hypothesis: there is a significant difference between public universities and private universities with regard to the relationship between employer brand and faculty members' retention.

\section{Research methods}

\subsection{Research Measures}

The questionnaire consisted of 25 items, split into 2 parts for measurement of employer brand and employee retention. The responses were measured by using the following five-point Likert scale: strongly agree (5)- to strongly disagree (1).

- Independent Variable will be measured through 14 statements, consisting of (development value dimension) 
The Impact of Employer Brand on Faculty Members Retention ...

Afnan mamdouh el sayed huessin barakat

through five statements, (economic value dimension) through four statements, (application dimension) through five statements (Berthon et al., 2005).

- Dependent variable (Retention) will be measured through 11 statement depending on the Likert scale (five). It ranges from strongly agree (5) to strongly disagree (1) based on Kyndt et al., (2009).

Research design shows the research plan that includes data collection, measurement, analysis, research strategy, and time horizon (Sekaran \& Bougie,2016).

This research employed a deductive cross-sectional research study. As the deductive research approach always begins with a hypothesis, the survey tests 3 main hypotheses derived from theory and based on the results of the surveys conducted in the first stage of the study (Sekaran\& Bougie,2016).

\subsection{Research Methodology}

Cross-sectional studies collect information from respondents in a single time period using the cross-sectional type of survey (Saunders et al., 2009; Bougie\& Sekaran 2016). Descriptive research design is used as the basis for research and its logic is based on statistics of research analysis. The descriptive method used is the "survey method". Selfadministered questionnaires were e-mailed to faculty members of the selected universities. Using the descriptive research design, 
The Impact of Employer Brand on Faculty Members Retention ...

Afnan mamdouh el sayed huessin barakat

the researcher will describe and interpret the results of the survey in terms of employee retention. Explaining the reasons for the results, an analytical methodology was adopted in the survey. This method enables the researcher to use the survey results, analyze them, and critically evaluate the employer brand dimensions that lead to faculty retention in the selected universities (Saunders et al., 2009; Bougie\& Sekaran 2016).

\subsection{Data collection techniques:}

The questionnaires were sent to the faculty of the selected universities via email. The researcher relied on this method as data were collected during Covid 19 in December 2020 until the end of February 2021. The questionnaires were sent to all faculty members in the selected colleges, where opportunities were equal for all sample units. The answers were random and not all faculty members responded to the questionnaire, in addition to the researcher's inability to control the scientific degree of the groups that responded, as well as their number. Accordingly, the researcher selected the quota sample technique.

\subsubsection{Research Population and How the Study was}

\section{Conducted}

- After conducting the field survey in various public and private universities in Egypt, the researcher concludes that the most brand name among universities are Cairo University, GUC University, BUE University and Suez Canal University. In addition, they gained the first

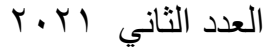


The Impact of Employer Brand on Faculty Members Retention ...

Afnan mamdouh el sayed huessin barakat

positions in universities ranking among universities in Egypt according to ARWU, QS and THE of universities ranking in Egypt 2020. Furthermore, they have the greater number of faculty members compared with other public and private universities in Egypt based on the central agency for public mobilization \& statistics 2020 .

- The researcher also concludes that there is no difference between Scientific and theoretical faculties with respect to factors affect staff retention especially development value and compensation and benefits. In addition, the research is limited to the selection of two practical and theoretical faculties with the largest number of faulty members in each University.

\section{The research sample: -}

The sample is crucial for increasing the validity of the collected data and ensuring that the sample is representative of a population. The research depended on Quota sampling. Quota sampling can be considered as a form of proportional stratified sampling, in which people are sampled from different groups, but on the basis of convenience (Sekaran\& Bougie,2016). The population is heterogeneous.

Statistical tables were used to determine the sample size. According to these tables, the size of the population is (3036) faculty members which ranges between the sizes of the community of 2500 and 3500 faculty members. Since the sample

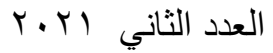

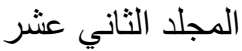


The Impact of Employer Brand on Faculty Members Retention ...

Afnan mamdouh el sayed huessin barakat

size corresponding to these samples is 333 and 346 faculty members, the sample size used in this research will be 340 faculty members, the closest to the population, with the size of 3036 faculty members, and with confidence interval 95\%and margin of error $5 \%$.

The sample size from each university is determined based on the percentage of faculty members from each university to the total sample size.

The number of responses reached 350 answers, and 60 questionnaires were excluded because they were not from the selected colleges and others were not from the selected universities. The researcher also excluded 50 randomly generated questionnaires from Suez Canal University and 20 questionnaires from BUE University in order to maintain the relative distribution between the population and the sample. Total valid questionnaires for analysis were 220 .

\section{Applied Research Results and Conclusion:}

This part presented a summary of the researcher's most important findings regarding the results of the field study as follows:

- Through the statistical analysis, it was found that the dimensions and measurements of each variable are consistent with validity and reliability. The KMO value for independent variable (employer brand) is .874 and Bartlett's test is significant $(\mathrm{p}=.000)$. Therefore, factor

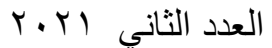

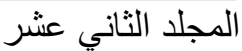


The Impact of Employer Brand on Faculty Members Retention ...

Afnan mamdouh el sayed huessin barakat

analysis is appropriate. Cronbach's Alpha coefficient for all variables exceeded 0.7 .

- The researcher found that the correlation of each independent variable is not more than 0.7 , and that there are no correlations between the independent variables. There is a positive correlation between the independent dimensions and the dependent variable.

- The value of $\mathrm{R}^{2}$ is equal to 0.476 . This means that the model, with all its independent variables, is able to predict (employee retention) at a rate of $47.6 \%$ and is considered a large predictor rate.

\section{As for testing the hypotheses, the results yielded the}

\section{following:}

There is partial acceptance of the first main hypothesis. This means that the employer brand has a partial effect on faculty retention in public and private universities. The main hypothesis was partly accepted because the main hypothesis consists of four sub-hypotheses. The first and the third sub-hypothesis were accepted, and the second and fourth sub-hypotheses were rejected. Thus, the first hypothesis was partially accepted. This is illustrated as follows: 
The Impact of Employer Brand on Faculty Members Retention ...

Afnan mamdouh el sayed huessin barakat

H1a: There is a significant direct and positive effect between development value and faculty members' retention.

- The results of the statistical analysis resulted in the acceptance of the first sub-hypothesis.

At a significant level less than $0.05(\mathrm{p}=.000)$ Development value can influence faculty members retention by $34 \%$. This indicates that the development value has a positive impact on the retention of faculty members in the selected universities. When faculty members feel that their university is concerned with the development and the improvement of their skills and knowledge through training programs, career growth and career advancement opportunities, this results in positive behaviors and attitudes of faculty members in relation to their universities. Faculty members become more committed, have intentions to stay in the university, and feel loyalty and belonging to the university, etc.

\section{H1b: There is a significant direct and positive effect between economic value and faculty members' retention.}

- The results of the statistical analysis resulted in the rejection of the second sub-hypothesis.

At a significant level more than $0.05(\mathrm{p}=0.117)$, economic value can influence faculty members retention by $10.2 \%$. This means that the economic value does not affect the retention of faculty members in the chosen universities, as the faculty members enjoy job security in public universities, but are 
The Impact of Employer Brand on Faculty Members Retention ...

Afnan mamdouh el sayed huessin barakat

completely dissatisfied with the rest of the economic value factors such as salaries, bonuses, etc., and they are always demanding to improve it. In private universities, the economic value is higher than that in public universities, but faculty members in private universities do not feel safe.

\section{H1c: There is a significant direct and positive effect between application value and faculty members' retention}

- The results of the statistical analysis resulted in the acceptance of the third sub-hypothesis.

At a significant level less than 0.05 ( $\mathrm{p}=.000)$, application value can influence faculty members retention by $29.6 \%$. This means that the value of the application has a positive effect on the retention of faculty members in the universities that have been selected. The more opportunity for a faculty member to share his information, apply what he has learned and acquire skills, and exchange experiences with colleagues, the more the faculty member's intention to continue in the university increases.

The hypothesis was accepted by faculty members in private and public universities, and this result is logical because universities work to improve the conditions and development of society through medical convoys, various consultations, lectures and seminars for school students in different stages, the last of which is the Child University, in which all universities participated to spread the culture of entrepreneurship among 
The Impact of Employer Brand on Faculty Members Retention ...

Afnan mamdouh el sayed huessin barakat

children, and other various services to society. In addition to the tendency of universities to improve their global rankings among the world's universities, each university's keenness to excel and advance in the rankings, international publication by university faculty members is a contributing factor in improving the university's global ranking. Universities have tended to hold workshops where faculty members lecture, giving them the opportunity to share their skills and knowledge with their colleagues within the university.

\section{H2: Development value is the most affecting factor on faculty members retention.}

- The results of the statistical analysis resulted in the acceptance of the second main hypothesis.

Development value is the most influential factor in faculty members' retention as it has the highest beta value 34\%. Faculty members strive to continuously develop their knowledge and skills, and this requires attending many training and scientific conferences. It is also looking for opportunities for career advancement and growth. This value is most important for faculty members, so many faculty members seek to travel abroad to participate in scientific conferences or to obtain a post-doctoral degree to enable them to develop their skills and knowledge.

H3: There is a significance difference between public universities and private universities with regard to the relationship between employer brand and faculty members' retention.

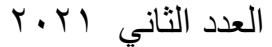

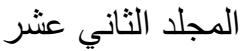


The Impact of Employer Brand on Faculty Members Retention ...

Afnan mamdouh el sayed huessin barakat

- The results of the statistical analysis resulted in the rejection of the third main hypothesis.

The influence of employer brand on faculty retention does not differ in public universities from private universities. This result is due to the fact that faculty members go to private universities in order to improve their financial conditions. Few of them go to private universities in pursuit of a better work environment and friendly relations among colleagues, as evidenced by the pilot study. Private universities have excessive workloads, intensive study schedules, and administrative work within the college, in addition to the scientific conferences in which the college participates.

Public universities are distinguished by the presence of job security. As we mentioned before, many faculty members prefer to allocate specific days per week to work in private universities while continuing their university job at their university out of loyalty and a sense of belonging to their university.

\section{Recommendations}

\section{For improving development value}

1. Conducting a training need analysis at each college level in each university to accurately determine what faculty members need to improve their career path in the various colleges.

2. Activating international exchange programs through making agreements between Egyptian and foreign universities. 
The Impact of Employer Brand on Faculty Members Retention ...

Afnan mamdouh el sayed huessin barakat

3. Ensuring the development of basic skills for research preparation such as scientific writing, statistical analysis, international publishing, how to obtain funding for research,

4. Ensuring the quality of the training process.

\section{For improving application value}

1. Encouraging faculty members to exchange knowledge experiences, and know-how especially in practical colleges.

2. Encouraging faculty members to present ideas for community service and the establishment of medical convoys, education, and awareness.

3. Forming working groups from different disciplines within the university to conduct research on specific topics.

\section{References:}

1. Ahmad, N. A., \& Daud, S. (2016). Engaging people with employer branding. Procedia Economics and Finance, 35, PP.690-698. doi: 10.1016/S2212-5671(16)00086-1.

2. Akther, S., \& Tariq, J. (2020). The Impact of Effective Training on Employee Retention: A Study in Private Banks of Bangladesh. Journal of Economics and Business, 3(1), pp. 96-114.

3. Ambler, T., \& Barrow, S. (1996). The employer brand. Journal of brand management, 4(3), pp.185-206.

4. Arasanmi, C. N., \& Krishna, A. (2019). Employer branding: perceived organizational support and employee retention-the mediating role of organizational commitment. Industrial and Commercial Training,51 (3), pp. 174-183.

5. Backhaus, K. (2016). Employer branding revisited. Organization Management Journal, 13(4), pp.193-201. 
The Impact of Employer Brand on Faculty Members Retention ...

Afnan mamdouh el sayed huessin barakat

6. Berthon, P., Ewing, M., \& Hah, L. L. (2005). Captivating organization: dimensions of attractiveness in employer branding. International journal of advertising, 24(2), pp. 151-172.

7. Bibi, P., Ahmad, A., \& Majid, A. H. A. (2018). The impact of training and development and supervisor support on employee's retention in academic institutions: The moderating role of work environment. Gadjah Mada International Journal of Business, 20(1), pp.113-131.

8. Bibi, P., Pangil, F., Johari, J., \& Ahmad, A. (2017). The Impact of Compensation and Promotional Opportunities on employee retention in Academic Institutions: The Moderating Role of Work Environment. International Journal of Economic Perspectives, 11(1).

9. Biswas, M. K., \& Suar, D. (2016). Antecedents and consequences of employer branding. Journal of Business Ethics, 136(1), pp.57-72.

10. Bussin, M., \& Mouton, H. (2019). Effectiveness of employer branding on staff retention and compensation expectations. South African Journal of Economic and Management Sciences, 22(1), pp.1-8.

11. Butt, A., Lodhi, R. N., \& Shahzad, M. K. (2020). Staff retention: a factor of sustainable competitive advantage in the higher education sector of Pakistan. Studies in Higher Education, 45(8), pp.1584-1604.

12. Chawla, P. (2019). Impact of employer branding on employee engagement in business process outsourcing (BPO) sector in India: mediating effect of person-organization fit. Industrial and Commercial Training, 52 (1), pp. 35-49.

13. Dabirian, A., Paschen, J., \& Kietzmann, J. (2019). Employer branding: Understanding employer attractiveness of IT companies. IT Professional, 21(1), pp.82-89. 
The Impact of Employer Brand on Faculty Members Retention ...

Afnan mamdouh el sayed huessin barakat

14. Fasih, ST, Jalees, T., \& Khan, MM, (2019) Antecedents to Employer Branding. Market Forces, 14(1), pp.81-106.

15. Gilani, H., \& Cunningham, L. (2017). Employer branding and its influence on employee retention: A literature review. The Marketing Review, 17(2), pp.239-256.

16. Gregorka, L., Silva, S., \& Silva, C. (2020). Employer branding practices amongst the most attractive employers of IT and engineering sector. International Journal of Human Capital and Information Technology Professionals (IJHCITP), 11(1), pp.1-16.

17. Hadi, N., \& Ahmed, S. (2018). Role of Employer Branding Dimensions on EMPLOYEE RETENTION: Evidence from Educational Sector. Administrative Sciences, 8(3), pp.44.

18. Hamidizadeh, A., \& Mohammadnezhad Fadardi, M. (2019). The brand of a university as an employer. Human Systems Management, 38(1), pp.73-86.

19. Ibrahim, N. S., Hashim, J., \& Rahman, R. A. (2018). The impact of employer branding and career growth on talent retention: The mediating role of recruitment practices in the Malaysian public sector. International Journal of Academic Research in Business and Social Sciences, 8(6), pp. 1034-1039.

20. Javed, B., \& Jaffar, M. (2019). Impact of Succession Planning on Employee Retention. Master Thesis in General Management. Jönköping university. Available at: https://www.divaportal.org/smash/get/diva2:1319437/FULLTEXT01.pdf.

21. Kossivi, B., Xu, M., \& Kalgora, B. (2016). Study on determining factors of employee retention. Open Journal of Social Sciences, 4(05), pp. 261-268 
The Impact of Employer Brand on Faculty Members Retention ...

Afnan mamdouh el sayed huessin barakat

22. Kyndt, E., Dochy, F., Michielsen, M., \& Moeyaert, B. (2009). employee retention: Organisational and personal perspectives. Vocations and Learning, 2(3), pp.195-215.

23. Matimbwa, H., \& Ochumbo, A. (2019). Academic Staff Motivation and Retention in Higher Learning Institutions in Tanzania: Evidence from Selected Universities in Iringa Region. Economic Research, 3(6), pp.1-14.

24. Miller, J. M., \& Youngs, P. (2021). Person-organization fit and firstyear teacher retention in the United States. Teaching and Teacher Education. Elsevier Ltd. 97, pp103226. https://doi.org/10.1016/j.tate.2020.103226 0742-051

25. Moore, S. J., Durst, P. T., Ritter, C., Nobrega, D., \& Barkema, H. W. (2020). Effects of employer management on employee recruitment, satisfaction, engagement, and retention on large US dairy farms. Journal of Dairy Science, 103(9), pp.8482-8493.

26. Mostafa, B. A., El-Borsaly, A. A. E., Hafez, E. A. E., \& Hassan, S. A. (2021). The Mediating Effect of Person-Organization Value Fit on the Relationship Between University branding and Academic Staff Citizenship Behavior. Academic Journal of Interdisciplinary Studies, 10(1), pp.313-313.

27. Moustafa, B.A., \& Hassan, S. A. (2020). University Branding Impact on Academic Staff Commitment in the Egyptian Private Higher Education Sector. British Academy of Management (BAM) conference proceedings.IN THE CLOUD.

28. Sarmad, M., Ajmal, M. M., Shamim, M., Saleh, M., \& Malik, A. (2016). Motivation and Compensation as Predictors of Employees' Retention: Evidence from Public Sector Oil and Gas Selling Organizations. Journal of Behavioural Sciences, 26(2), PP.174-188. 
The Impact of Employer Brand on Faculty Members Retention ...

Afnan mamdouh el sayed huessin barakat

29. Saunders, M., Lewis, P., \& Thornhill, A. (2009). Research methods for business students. Pearson education.

30. Sekaran, U., \& Bougie, R. (2016). Research methods for business: A skill building approach. John Wiley \& Sons.

31. Tanwar, K. (2017). The Effect of Employer Brand Dimensions on Organisational Commitment: Evidence from Indian IT Industry. Asia-Pacific Journal of Management Research and Innovation, 12(3-4), pp.282-290.

32. Tanwar, K., \& Prasad, A. (2016). Exploring the relationship between employer branding and employee retention. Global Business Review, 17(3_suppl), 186S-206S.

33. Towns, A. (2019). Effective Strategies to Increase Employee Retention in Higher Education Institutions. Walden University, Walden Dissertations and Doctoral Studies Collection at Scholar Works. available in: https://scholarworks.waldenu.edu/dissertations.

34. Wadhawan, S., \& Sinha, S. (2020). A Study of Employer Branding on Employee Attitude. https://www.researchgate.net/publication/316597546_A_study_of_e mployer_branding_on_employee_attitude.

35. Younis, R.A.A. \&Hammad, R. (2020). Employer image, corporate image and organizational attractiveness: The moderating role of social identity consciousness. Personnel Review, Ahead of print, https://doi.org/10.1108/PR-02-2019-0058.

36. Younis, R.A.A. (2020). How Does Employer Brand Influence Employees' Openness to Change? The Mediating Role of Organizational Identification and Work Meaningfulness. British Academy of Management (BAM) conference proceedings 